\title{
Hubungan Antara Manajemen Waktu dan Prokrastinasi Akademik Mahasiswa PG-PAUD FKIP UNILAK
}

\author{
Reswita \\ Universitas Lancang Kuning \\ Email: reswita@unilak.ac.id
}

\begin{abstract}
Abstrak
Mahasiswa yang mempunyai kualitas Sumber Daya Manusia (SDM) yang unggul dapat ditunjukkan dengan perilaku disiplin, kreativitas, maupun etos kerja yang tinggi dalam mengerjakan tugas dan kewajibannya selama mengikuti proses pembelajaran di perguruan tinggi. Apabila seorang mahasiswa memiliki konsep belajar yang baik maka seorang mahasiswa tidak akan melakukan penundaan dalam melaksanakan kuliahnya. Namun sebagian mahasiswa masih melakukan penundaan dalam tugas akademiknya yang dikenal dengan prokrastinasi akademik. Banyak ahli berusaha memberikan penyelesaian bagi masalah prokrastinasi. Beberapa ahli atau penulis buku menyarankan penggunaan manajemen waktu. Dengan menerapkan manajemen waktu diharapkan ada manfaat yang bisa diperoleh oleh mahasiswa. Penelitian ini bertujuan untuk mengetahui hubungan antara manajemen waktu dengan prokrastinasi akademik mahasiswa PG-PAUD FKIP UNILAK semester 6 tahun 2017/2018 yang berjumlah 29 orang. Penelitian ini merupakan penelitian korelasi. Data dikumpulkan dengan menggunakan angket dan dianalisis menggunakan analisis korelasi dengan bantuan program statistical package for social sciences (SPSS) for windows versi 21. Hasil penelitian menunjukkan bahwa terdapat hubungan antara manajemen waktu dan prokrastinasi akademik mahasiswa dengan taraf signifikansi 0,022.
\end{abstract}

Kata kunci: Manajemen, Prokrastinasi, Akademik

\section{Relationship Between Time Management And Academic Prokrastinasi Students PG-PAUD FKIP UNILAK}

\begin{abstract}
The student who has the quality of human resources can be shown with a superior behavior discipline, creativity, as well as a high work ethic in doing tasks and obligations for following the process of learning in college. If a student has a learning concept is good then a student will not do the delays in carrying out his studies. But some students still do delays in academic tasks, known as the academic prokrastinasi. Many experts attempt to provide a settlement for the problem of prokrastinasi. Some experts recommend using author or time management. By applying time management expected benefits to be gained by the student. This research aims to know the relationship between time management with academic
\end{abstract}


prokrastinasi students PG-PAUD FKIP UNILAK that add up to 29 people. This research is the research of the correlation. The data collected by using question form and analyzed using the correlation analysis with the help of the program of statistical package for social sciences (SPSS) for windows version 21. The results showed that there is a relationship between time management and academic prokrastinasi students with degrees of significance of 0.022 .

\section{Keywords: Management, Prokrastinasi, Academic}

\section{PENDAHULUAN}

Prokrastinasi berasal dari bahasa Latin yaitu procrastinare. Kata procrastinare merupakan kata yang terbentuk dari awalan pro yang berarti bergerak maju dan akhiran crastinus yang berarti mempunyai hari esok Burka dan Yuen (2008), jika digabungkan, kata procrastinare berarti menunda untuk hari berikutnya. Prokrastinasi dapat diartikan perilaku yang sering menunda-nunda baik tugas maupun pekerjaan yang seharusnya dikerjakan sesuai dengan waktu yang telah ditetapkan, pelaku yang melakukan proktastinasi disebut prokrastinator.

Prokrastinasi adalah

kecenderungan untuk menunda atau menghindari sepenuhnya tanggung jawab, keputusan, atau tugas yang perlu dilakukan (Mc. Carthy, dkk. dalam LaForge, 2008). Prokrastinasi menurut Solomon dan Rothblum (dalam Brownlow dan Reasinger, 2000) adalah penundaan mulai pengerjaan maupun penyelesaian tugas yang disengaja. Dari definisi tersebut dapat dilihat bahwa perilaku prokrastinasi adalah perilaku yang disengaja, dalam arti bahwa faktorfaktor dalam menunda pengerjaan atau penyelesaian tugas berasal dari putusan dirinya sendiri.

Menurut M. N. Ghufron (2003), "pengertian prokrastinasi dapat dipandang dari berbagai batasan tertentu, yaitu (1) prokrastinasi hanya sebagai perilaku penundaan, yaitu bahwa setiap perbuatan untuk menunda dalam mengerjakan tugas disebut sebagai prokrastinasi, tanpa mempermasalahkan tujuan serta alasan penundaan yang dilakukan; prokrastinasi sebagai suatu kebiasaan atau pola perilaku yang dimiliki individu, yang mengarah kepada trait (kebiasaan), penundaan yang dilakukan sudah merupakan respon tetap yang selalu dilakukan seseorang dalam menghadapi tugas, biasanya disertai oleh adanya keyakinan- keyakinan yang irasional; (3) prokrastinasi sebagai trait (kebiasaan) yang melibatkan komponen-komponen perilaku maupun struktur mental lain yang saling terkait yang dapat diketahui secara langsung maupun tidak langsung".

Prokrastinasi dapat diartikan perilaku yang sering menunda-nunda baik tugas maupun pekerjaan yang seharusnya dikerjakan sesuai dengan waktu yang telah ditetapkan. Menurut Solomon \& Rothblum, 1984 (dalam 
Ghufron, 2004) prokrastinasi yaitu suatu kecenderungan untuk menunda-nunda dalam memulai maupun menyelesaikan suatu tugas secara keseluruhan untuk melakukan aktivitas lain yang tidak berguna sehingga kinerja menjadi terhambat. Pelaku yang melakukan proktastinasi disebut prokrastinator. Prokrastinasi dalam bidang akademik dinamakan dengan prokrastinasi akademik.

Prokrastinasi akademik dan nonakademik sering menjadi istilah yang digunakan oleh para ahli untuk membagi jenis-jenis tugas. Prokrastinasi akademik adalah jenis penundaan yang dilakukan pada jenis tugas formal yang berhubungan dengan tugas akdemik, misalnya tugas kuliah dan skripsi. Prokrastinasi nonakademik adalah penundaan yang dilakukan pada jenis tugas non-formal atau tugas yang berhubungan dengan kehidupan sehari-hari, misalnya tugas rumah tangga, tugas sosial, tugas kantor dan lain sebagainya.

Menurut Clark \& Hill dalam (Wolter, 2003) bahwa: prokrastinasi akademik sering muncul pada pelajar dan mahasiswa. Hal ini memiliki efek yang negatif terhadap proses belajar dan prestasi belajar. Selain itu, perilaku ini dapat menyebabkan pengumpulan tugas yang terlambat, kecemasan menjelang ujian, sikap menyerah pada mahasiswa dan lebih jauh lagi berakibat terhadap hasil ujian serta mempengaruhi aktivitas lainnya dalam lingkungan sekolah atau kampus.

Prokrastinasi akademik terjadi karena adanya keyakinan tidak rasional yang dimiliki oleh mahasiswa. Keyakinan tidak rasional tersebut dapat disebabkan oleh kesalahan dalam mempersepsikan tugas, yaitu memandang tugas sebagai sesuatu yang berat dan tidak menyenangkan. Selain itu mahasiswa menunda-nunda mengerjakan tugas karena takut jika gagal menyelesaikannya sehingga akan mendatangkan penilaian yang negatif akan kemampuannya. Akibatnya seseeorang menunda-nunda untuk mengerjakan tugas yang dihadapinya.

Sementara itu, Kartadinata dan Tjundjing (2008) mengungkapkan faktor-faktor lain yang menyebabkan munculnya prokrastinasi akademik antara lain:

a. Masalah manajemen waktu

Manajemen waktu melibatkan proses menentukan kebutuhan (determining needs), menetapkan tujuan untuk mencapai kebutuhan (goal setting), mem- prioritaskan dan merencanakan (plan- ning) tugas yang diperlukan untuk mencapai tujuan.

b. Penetapan prioritas

Hal ini penting supaya individu bisa menangani semua masalah atau tugas secara runtut sesuai dengan kepen- tingannya.

c. Karakteristik tugas

Individu cenderung akan menunda mengerjakan tugas apabila dinilai sulit oleh individu tersebut. Hal ini juga dipengaruhi faktor motivasi baik intrinsik maupun ekstrinsik siswa.

Menurut Surijah dan Tjundjing (2007) aspek-aspek pada prokrastinasi akademik terdiri dari 4 hal, yaitu:

a. Perceive

d time

Merupakan kecenderungan 
seorang prokrastinator salah satunya gagal menepati deadline.

b. Intentionaction gap

Merupakan celah antara keinginan dan perilaku.

c. Emotional

distress

Merupakan salah satu aspek yang tampak dari perasaan cemas saat melakukan prokrastinasi.

d. Perceived

ability

Merupakan keyakinan terhadap kemampuan diri pada seseorang. Keragu-raguan seseorang terhadap kemampuan diri akan menyebabkan seseorang melakukan prokrastinasi.

Menurut Ferrari, dkk. (1995), prokrastinasi akademik dapat termanifestasikan dalam indikator tertentu yang dapat diukur dan diamati dengan ciri- ciri berupa:

a. Penundaan untuk memulai maupun menyelesaikan kerja pada tugas yang dihadapi.

Seseorang yang melakukan prokras- tinasi tahu bahwa tugas yang di- hadapinya harus segera diselesaikan dan berguna bagi dirinya, akan tetapi dia menunda-nunda untuk mulai mengerjakannya atau menunda-nunda untuk menyelesaikan sampai tuntas jika dia sudah mulai mengerjakan sebelumnya.

b. Keterlambatan dalam mengerjakan tugas.

Individu yang melakukan prokrastinasi memerlukan waktu yang lebih lama daripada waktu yang dibutuhkan pada umumnya dalam mengerjakan suatu tugas. Seorang prokratinator meng- habiskan waktu yang dimilikinya untuk mempersiapkan diri secara berlebihan, maupun melakukan hal-hal yang tidak dibutuhkan dalam penyelesaian suatu tugas, tanpa memperhitungkan keterbatasan waktu yang dimilikinya.

c. Kesenjangan waktu antara rencana dan kinerja aktual.

Seorang prokrastinator mempunyai ke- sulitan untuk melakukan sesuatu sesuai dengan batas waktu yang telah ditentukan sebelumnya. Seorang prok- rastinator sering mengalami keter- lambatan dalam memenuhi deadline yang telah ditentukan, baik oleh orang lain maupun rencana yang telah dia tentukan sendiri.

d. Melakukan aktivitas lain yang lebih menyenangkan daripada melakukan tugas yang harus dikerjakan.

Seorang prokrastinator dengan sengaja tidak segera melakukan tugasnya, akan tetapi menggunakan waktu yang dia miliki untuk melakukan aktivitas lain yang dipandang lebih menyenangkan dan mendatangkan hiburan, seperti membaca (koran, majalah, atau buku cerita lainnya), menonton, mengobrol, berjalan-jalan, mendengarkan musik, dan sebagainya, sehingga menyita waktu yang dia miliki untuk me- ngerjakan tugas yang harus diselesaikannya.

e. Karakter individu 
Mencakup perasaan kurang percaya diri, moody, dan keyakinan tak rasional. Individu cenderung melakukan pe- nundaan jika merasa kurang percaya diri dalam melaksanakan tugas karena takut terjadi kesalahan. Burka dan Yuen (2008) menegaskan aspek keyakinan tak rasional yang dimiliki individu, bahwa individu memiliki pandangan tugas harus diselesaikan dengan sem- purna, sehingga merasa lebih aman jika tidak mengerjakannya.

Menurut Ghufron dan Risnawati (2011), prokrastinasi akademik dipengaruhi oleh dua faktor yaitu faktor dari dalam individu (internal) dan eksternal. Faktor internal merupakan faktor yang muncul dari dalam diri individu berupa sikap pengaturan diri dalam belajar atau biasa disebut dengan self-regulated learning. Faktor eksternal merupakan faktor yang muncul dari luar individu, misalnya dari pengaruh teman.

Menurut beberapa penelitian, manajemen waktu dapat mengurangi perilaku prokrastinasi akademik. Manajemen waktu adalah cara yang dapat dilakukan untuk menyeimbangkan waktu untuk kegiatan belajar atau bekerja, untuk bersenang-senang atau bersantai, dan beristirahat secara efektif. Tanpa disadari, setiap saat sesungguhnya kita telah membuat beberapa putusan terkait manajemen waktu. Misal, memutuskan kapan akan ke kampus, belajar di rumah, berolahraga, beribadah, mengunjungi perpustakaan, bersantai, berdiskusi dengan teman, berbelanja, dan sebagainya. Semua putusan ini berperan penting di dalam penyusunan strategi manajemen waktu.

Claessens et al. (2007) menyimpulkan manajemen waktu sebagai "tindakan yang bertujuan untuk memperoleh sebuah penggunaan waktu yang efektif ketika melakukan tindakan tertentu yang mengarah pada tujuan. Manajemen waktu melibatkan proses menentukan kebutuhan (determining needs), menetapkan tujuan untuk mencapai kebutuhan (goal setting), memprioritaskan, dan merencanakan (planning) tugas yang diperlukan untuk mencapai tujuan.

Jika kita dapat menyeimbangkan waktu, maka diharapkan hasilnya adalah konsentrasi akan meningkat, organisasi waktu akan lebih baik, produktifitas akan meningkat, dan terpenting tingkat stress akan terkurangi. Dengan menata waktu secara lebih baik maka kita akan menemukan keseimbangan antara kapan harus belajar, bekerja, bersantai, dan beristirahat yang akhirnya akan membuat seseorang lebih mudah dalam mencapai kesuksesan.

Permasalahan yang ditemukan di lapangan yaitu banyaknya mahasiswa yang menunda-nunda dalam mengerjakan tugas. Seringkali mahasiswa terlambat dalam mengumpulkan tugas yang diberikan oleh dosen. Keterlambatan ini disebabkan oleh berbagai faktor. Ada yang karena mahasiswa memang malas mnegerjakan tugas, ada pula karena mahasiswa yang terlalu sibuk dengan kegiatan lain seperti organisasi mahasiswa sehingga tidak bisa menyeimbangkan waktu untuk membuat tugas dan organisasi.

Dengan demikian banyak mahasiswa yang mendapatkan nilai 
yang tidak sesuai dengan yang diharapkan. Hal ini disebabkan karena tugas belum lengkap dan sebagainya.

Berdasarkan permasalahan di atas maka penulis merasa perlu mengadakan penelitian dengan judul “ Hubungan antara Manajemen Waktu dan Prokrastinasi Akademik Mahasiswa PG-PAUD FKIP UNILAK".

\section{METODE}

\section{A. Jenis Penelitian}

Berdasarkan tujuan penelitian, maka jenis penelitian yang digunakan adalah penelitian deskriptif korelasional yang bertujuan untuk menemukan faktafakta yang sesuai dengan keadaan yang sebenarnya. Menurut A. Muri Yusuf (2005:84) "penelitian korelasional merupakan suatu tipe penelitian yang melihat hubungan antara satu atau beberapa ubahan dengan satu atau beberapa ubahan lain". Penelitian ini untuk menemukan hubungan antara manajemen waktu (X) dengan prokrastinasi akademik mahasiswa (Y).

\section{B. Waktu Dan Tempat Penelitian}

Penelitian ini telah dilakukan di Fakultas Keguruan dan Ilmu Pendidikan Universitas Lancang Kunging pada bulan Februari sampai dengan Mei 2018.

\section{Sampel Penelitian}

Sampel dalam penelitian ini adalah mahasiswa Program studi Pendidikan Guru Pendidikan Anak Usia Dini Fakultas Keguruan dan Ilmu Pendidikan Universitas Lancang Kunging semester 6 tahun 2017/2018 yang berjumlah 29 orang.

\section{Teknik Pengumpulan Data}

Alat yang digunakan untuk mengumpulkan data dalam penelitian ini adalah angket. Angket adalah teknik pengumpulan data dengan cara mengajukan pertanyaan tertulis untuk dijawab secara tertulis pula oleh responden. Angketmerupakan kumpulan pertanyaan-pertanyaan yang tertulis yang digunakan untuk memperoleh informasi dari responden tentang diri pribadi atau hal-hal yang ia ketahui. Menurut A. Muri Yusuf $(2005: 249)$ angket adalah suatu rangkaian pernyataan yang berhubungan dengan topik tertentu yang diberikan kepada sekelompok individu dengan maksud untuk memperoleh data.

Item pernyataan disusun menggunakan skala Likert, karena dianggap sesuai untuk menanyakan pendapat atau sikap seseorang terhadap suatu objek.

\section{E. Teknik Analisis Data}

Pengolahan data dilakukan setelah semua data terkumpul melalui angket. Data yang telah terkumpul diolah dengan langkah-langkah sebagai berikut:

1. Memeriksa kelengkapan isian data instrumen yang telah diterima dari sampel penelitian.

2. Membuat tabel pengolahan data.

3. Menskor dan menghitung jumlah jawaban responden serta memasukan dalam tabel pengolahan data.

4. Menganalisis data yang telah diperoleh dengan melakukan uji korelasi berbantuan Person Product Moment, dengan bantuan program SPSS for Windows 21.00. 


\section{HASIL DAN PEMBAHASAN}

Penelitian ini terdiri dari dua variabel yaitu variabel manajemen waktu (X) dan variabel prokrastinasi akademik (Y).

Berikut ini merupakan gambaran hasil uji korelasi antara manajemen waktu dengan prokrastinasi akademik mahasiswa yaitu "terdapat hubungan signifikan antara manajemen waktu dengan prokrastinasi akademik mahasiswa PG-PAUD FKIP UNILAK”. Pengujian korelasi menggunakan rumus Person Product Moment, dengan bantuan program SPSS for Windows 21.00. Hasilnya dapat dilihat pada tabel berikut ini:

Tabel 1. Hasil Uji Korelasi

\begin{tabular}{|c|c|c|c|}
\hline \multicolumn{4}{|c|}{ Correlations } \\
\hline & & MW & PA \\
\hline M & Pearson & 1 & $-.422^{*}$ \\
\hline \multirow[t]{3}{*}{ W } & Correlation & & \\
\hline & $\begin{array}{l}\text { Sig. (2- } \\
\text { tailed) }\end{array}$ & & .022 \\
\hline & $\mathrm{N}$ & 29 & 29 \\
\hline \multirow[t]{3}{*}{ PA } & $\begin{array}{l}\text { Pearson } \\
\text { Correlation }\end{array}$ & $-.422^{*}$ & 1 \\
\hline & $\begin{array}{l}\text { Sig. (2- } \\
\text { tailed) }\end{array}$ & .022 & \\
\hline & $\mathrm{N}$ & 29 & 29 \\
\hline
\end{tabular}

*. Correlation is significant at the 0.05 level (2-tailed).

Berdasarkan tabel di atas diperoleh nilai signifikan sebesar 0,022 . Nilai signifikan ini lebih kecil dari 0,05 sehingga dapat dikatakan bahwa terdapat hubungan antara manajemen waktu dengan prokrastinasi akademik mahasiswa PG-PAUD FKIP UNILAK.

Hal di atas sejalan dengan pendapat Kartadinata dan Tjundjing (2008) yang mengungkapkan bahwa faktor-faktor lain yang menyebabkan munculnya prokrastinasi akademik diantaranya yaitu masalah manajemen waktu. Dengan menata waktu secara lebih baik maka akan ditemukan keseimbangan antara kapan harus belajar, bekerja, bersantai, dan beristirahat yang akhirnya akan membuat seseorang lebih mudah dalam mencapai kesuksesan.

Leman (2007) mengartikan manajemen waktu yaitu menggunakan dan memanfaatkan waktu sebaikbaiknya, seoptimal mungkin melalui perencanaan kegiatan yang terorganisir dan matang. Dengan manajemen waktu seseorang dapat merencanakan dan menggunakan waktu secara efisien dan efektif sehingga tidak menyia-nyiakan waktu dalam kehidupannya. Perencanaan ini bisa berupa jangka panjang, menengah dan pendek.

\section{KESIMPULAN}

Berdasarkan hasil penelitian, maka penelitian ini dapat disimpulkan bahwa terdapat hubungan yang signifikan antara manajemen waktu dan prokrastinasi akademik mahasiswa PGPAUD FKIP UNILAK pada taraf signifikansi 0,022 .

Adapun saran yang diberikandalam penelitian ini adalah sebagai berikut:

1. Pihak kampus, agar membantu mahasiswa dalam meningkatkan kemampuan manajemen waktu dan mengurangi prokrastinasi akademik dengan memberikan layanan informasi seperti sosialisasi, seminar dan sebagainya. 
2. Lingkungan akademik, agar memberikan perlakuan atau contoh teladan yang baik kepada mahasiswa khususnya dalam hal manajemen waktu dan prokrastinasi akademik.

\section{DAFTAR PUSTAKA}

[1] A Muri Yusuf.2005. Metodologi Penelitian (Dasar-Dasar Penyelidikan Ilmiah). Padang: UNP Press.

[2] Burka J., \& Yuen, L. (2008). Procrastination is the thief of time. Diunduh 10 Februari, 2018, dari http://sas.calpoly.edu/asc/ssl/ procrastination.doc

[3] Claessens, B., Van Eerde, W., Rutte, C., \& Roe, R. (2007). A review of time management literature. Personnel Review, 36(2), 255-276.

[4] Ferrari, J., Johnson, J., \& McCown,W. (1995). Pro- crastination and task avoidance: Theory, research, and treatment. New York: Plenum Press.

[5] Ghufron, M. N. 2003. Hubungan Kontrol Diri dan Persepsi Remaja Terhadap Penerapan Disiplin Orang Tua dengan Prokrastinasi Akademik. Tesis.(tidak diterbitkan), Yogjakarta: Fakultas Psikologi Universitas Gadjah Mada.

[6] Ghufron, M.N., \& Risnawati, R.S. 2011. Teori-Teori Psikologi. Yogyakarta: Ar- Ruzz Media

[7] Reswita, R. (2017). HUBUNGAN POLA ASUH ORANGTUA DENGAN CAPAIAN PERKEMBANGAN

ANAK. PAUD Lectura: Jurnal Pendidikan Anak Usia Dini,1(1), 72-81.
[8] Sugiyono, (2008). Metode Penelitian Kunatitatif Kualitatif dan $R \& D$. Bandung Alfabeta.

[9] Surijah, E., \& Sia, T. (2007). Mahasiswa versus tugas:Prokrastinasi akademik dan conscientiousness. Anima, Indonesian Psychological Journal, 22(4), 352-374.

[10] Wahyuni, S., \& Reswita, R. (2017). Hubungan Kematangan Emosional terhadap Kemampuan Bersosialisasi Mahasiswa PGPAUD FKIP UNILAK. Lectura: Jurnal Pendidikan, 8(2).

[11] Wolters, C. (2003). Understanding procrastination from a self-regulated learning perspective. Journal of Educational Psychology, 3(1), 179187. 